\title{
POPULASI MOLUSKA PADA MUSIM KEMARAU DAN MUSIM HUJAN DI ZONA INTERTIDAL PANTAI SELATAN SUMBAWA
}

\author{
Oleh \\ Fredinan Yulianda *) dan Iis jubaedah **) \\ *) Dosen Fakultas Perikanan dan Ilmu Kelautan IPB Bogor \\ **) Dosen Jurusan Penyuluhan Perikanan Sekolah Tinggi Perikanan
}

\begin{abstract}
ABSTRAK
Penelitian mengenai moluska di wilayah pesisir Sumbawa Barat bagian selatan telah dilakukan pada musim kemarau (April) dan musim hujan (September) tahun 2007 di lima lokasi, yaitu Pantai Maluk, Mangkun, Madasanger, Sejorong dan Puna. Penelitian ini bertujuan untuk mengidentifikasi jenis, jumlah dan sebaran populasi moluska di zona intertidal pantai Selatan Sumbawa. Pengamatan biota dilakukan dengan metode transek kuadrat yang ditarik secara vertikal dari garis pantai. Hasil penelitian menunjukkan kepadatan rata - rata dan kisaran populasi moluska di pantai Maluk pada ketiga stasiun, berturut-turut, adalah 9 ind $/ \mathrm{m}^{2}, 8-30 \mathrm{ind} / \mathrm{m} 2$, dan 8 $40 \mathrm{ind} / \mathrm{m} 2$. Di pantai Mangkun, 20-30 ind $/ \mathrm{m}^{2}$, 10-68 ind $/ \mathrm{m}^{2}$, dan $23-100 \mathrm{ind} / \mathrm{m}^{2}$. Di pantai Madasanger 3-30 ind $/ \mathrm{m}^{2}$, 5-65 ind $/ \mathrm{m}^{2}$, dan $11-51 \mathrm{ind} / \mathrm{m}^{2}$. Di Pantai Sejorong 10-82 ind $/ \mathrm{m} 2,12-60 \mathrm{ind} / \mathrm{m}^{2}$, dan $10-83 \mathrm{ind} / \mathrm{m} 2$, dan selanjutnya di Pantai Puna (Tongoloka) 20-180 ind $/ \mathrm{m}^{2}$, 25-75 ind $/ \mathrm{m}^{2}$ dan $20-170 \mathrm{ind} / \mathrm{m}^{2}$. Kepadatan populasi moluska tertinggi dan relatif stabil terdapat di stasiun pasang tinggi pantai Puna yang bersubstrat berbatu, lebar flat sempit, dan curam. Kepadatan terendah terdapat di stasiun pasang rendah Pantai Maluk yang bersubstrat berbatu, pasir hingga pasir berkarang. Populasi moluska berfluktuasi dan sebaran meningkat pada musim hujan (September) dan menurun pada musim kemarau (April). Jenis populasi yang dominan adalah Oyster/Crassostrea dari kelas Pelecypoda dan Litorrina dari kelas Gastropoda.
\end{abstract}

Kata Kunci : populasi, musim ,zona, intertidal, Pantai Selatan Sumbawa

\section{PENDAHULUAN}

\section{Latar Belakang}

Moluska merupakan biota yang bertubuh lunak, bentuk tubuhnya sangat beranekaragam, dari bentuk silindris seperti cacing dan tidak mempunyai kaki maupun cangkang, sampai bentuk hampir bulat tanpa kepala dan tertutup dua keping cangkang besar. Tubuh moluska simetris bilateral, tertutup mantel yang

menghasilkan cangkang, dan mempunyai kaki ventral, hidupnya pada perairan dengan substrat dasar berbatu, pasir dan batu karang terutama didaerah litoral (intertidal). Zona Intertidal merupakan daerah pasang surut yang dipengaruhi oleh kegiatan pantai dan laut sehingga kondisi lingkungannya menjadi dinamis. 
Sebaran populasi moluska selalu berfluktuasi dan struktur komunitas biota bervariasi berdasarkan substrat dasarnya. Moluska memiliki nilai ekonomis yang penting sehingga keberadaannya perlu dilindungi.

Untuk melindungi moluska di zona intertidal maka identifikasi jenis, kepadatan dan sebaran populasi pada setiap musim mempunyai peran penting untuk melakukan kegiatan konservasi dan sebagai langkah awal dalam pengelolaan serta pengembangannya sehingga keberadaanya dialam tetap lestari.

\section{Tujuan Penelitian}

Penelitian ini bertujuan untuk mengidentifikasi jenis, jumlah dan sebaran populasi molusca di zona intertidal pantai Selatan Sumbawa.

\section{MATODE PENELITIAN}

Pengamatan biota intertidal dilakukan dua kali dalam setahun, yaitu pada musim panas (bulan April) dan musim hujan (September). Pengamatan biota intertidal (Moluska) dilakukan pada tanggal 11-15 April dan 8-12 September 2007 di lima lokasi pesisir Sumbawa Barat bagian selatan, yaitu Maluk, Mangkun, Madasanger, Sejorong dan Puna (Gambar1)

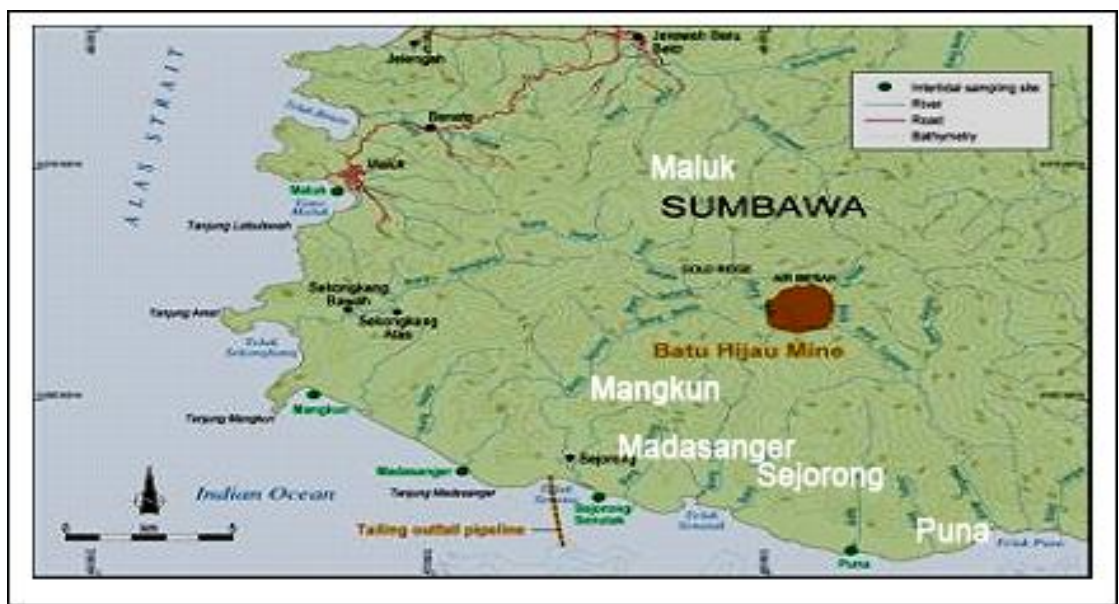

Gambar 1. Lokasi Pengamatan komunitas pasang surut di lima stasiun

Pengamatan biota dilakukan dengan metode transek kuadrat yang ditarik vertikal dari garis pantai. Setiap lokasi pengamatan terdiri dari tiga substasiun yaitu pasang atas, tengah dan pasang bawah dengan tiga ulangan. Jarak antara garis stasiun ulangan adalah 50 meter, sedangan jarak substasiun berkisar antara 50200 meter tergantung lebar dataran pasang surut (Gambar 2). 


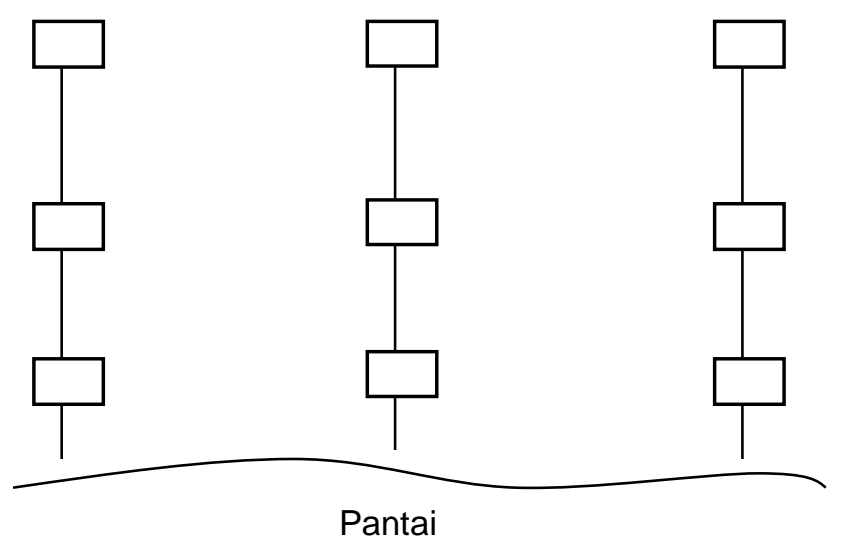

Gambar 2. Stasiun Pengamatan Moluska

\section{HASIL DAN PEMBAHASAN}

Maluk merupakan sebuah teluk dimana pantai sebelah Utara agak landai sehingga daerah pasang surut cukup lebar sekitar 400 meter. Tipe substrat berbatu, pasir hingga pasir berkarang. Populasi moluska mencapai kepadatan yang terendah pada bulan April 2007, dan mulai meningkat kembali pada bulan September 2007.

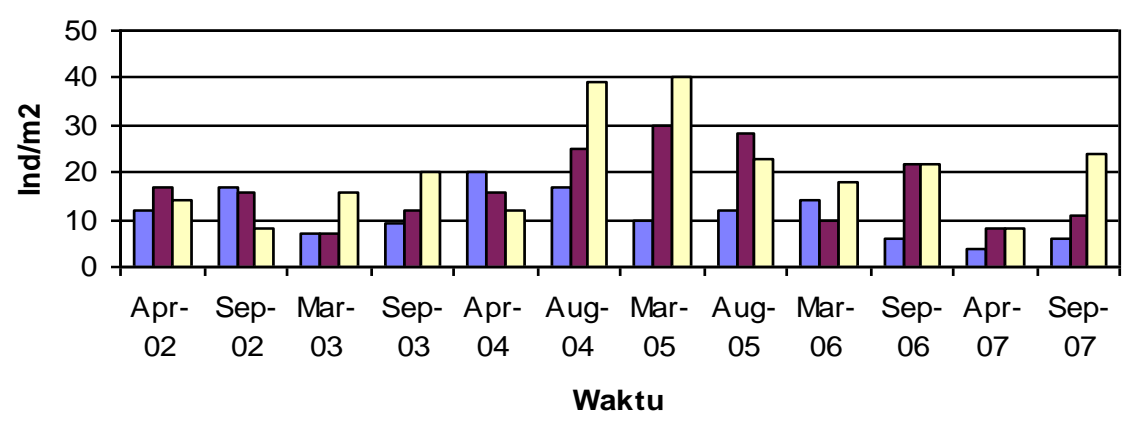

$\square$ Stasiun atas $\square$ Stasiun tengah $\square$ Stasiun baw ah

Gambar 3. Kepadatan fauna di Intertidal Maluk selama tahun 2002 -2007

Komunitas intertidal mempunyai daerah zonasi yang berbeda yang diperlihatkan kecenderungan keberadaannya. Populasi fauna cenderung lebih banyak di stasiun tengah dan bawah. Moluska tidak banyak ditemukan di stasiun pasang tinggi dengan kepadatan rata-rata 9 $\mathrm{ind} / \mathrm{m}^{2}$ (Gambar 3). Stasiun tengah memiliki topografi yang datar populasi fauna relatif lebih baik di stasiun tengah dengan kepadatan 8$30 \mathrm{ind} / \mathrm{m}^{2}$. Stasiun pasang rendah terletak di dekat laut Kepadatan fauna relatif tidak berbeda meskipun mengalami fluktuasi, yaitu $8-40$ ind $/ \mathrm{m}^{2}$. 
Wilayah pesisir Mangkun mempunyai flat pasang surut yang lebar yaitu sekitar 250-300 meter. Kondisi lingkungan perairan cukup bagus, cerah dan jernih. Namun demikian kondisi substrat karang umumnya banyak mati yang disebabkan oleh suhu yang terlalu panas dan gangguan manusia (penduduk) yang mencari biota laut. Pengamatan ekologi intertidal di Mangkun dilakukan pada bulan April dan September pada waktu surut rendah. Populasi fauna pada bulan April 2007 mengalami penurunan setelah September 2006 dan kembali mulai meningkat pada September 2007.

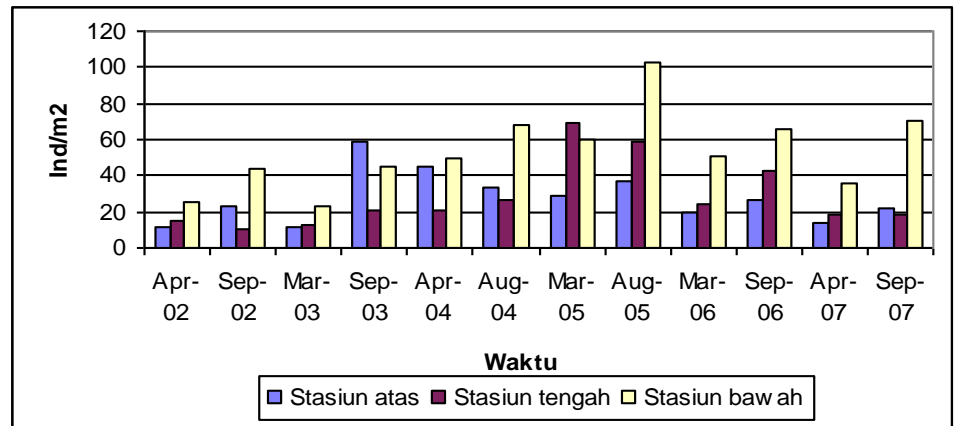

Gambar 4. Kepadatan fauna di Intertidal Mangkun selama tahun 2002 -2007

Komunitas intertidal Mangkun mempunyai daerah zonasi yang berbeda yang diperlihatkan kecenderungan keberadaannya. Populasi fauna cenderung lebih banyak di stasiun bawah. Stasiun pasang tinggi (dekat pantai) mempunyai substrat pasir dan endapan karang yang agak keras. Populasi fauna cenderung mengelompok dengan kepadatan sekitar 20-30 ind $/ \mathrm{m}^{2}$. Stasiun tengah tidak jauh berbeda dengan stasiun pasang tinggi meskipun substratnya lebih banyak terendam air laut. Populasi fauna cenderung menurun setelah mencapai puncak pada bulan Maret 2005. Kepadatan fauna di stasiun tengah berkisar 10-68 ind $/ \mathrm{m}^{2}$.

Stasiun pasang rendah (dekat laut) mempunyai substrat karang dan keras karena dekat dengan pecahan ombak. Populasi fauna di stasiun bawah ini mencapai puncak pada bulan Agustus 2005 dan menurun hingga April 2007 serta mulai meningkat pada bulan September 2007. Kepadatan fauna di daerah ini berkisar 23-100 ind $/ \mathrm{m}^{2}$.

Intertidal Madasanger cukup lebar hingga mencapai 350 meter dengan tipe substrat pasir, batu karang dan campuran. Pada stasiun pasang tinggi dan tengah banyak ditemukan lamun, terutama di stasiun tengah yang agak dalam terendam. Populasi fauna mencapai puncak pada bulan Agustus 2005, setelah itu rata-rata menurun hingga saat ini (September 2007). 


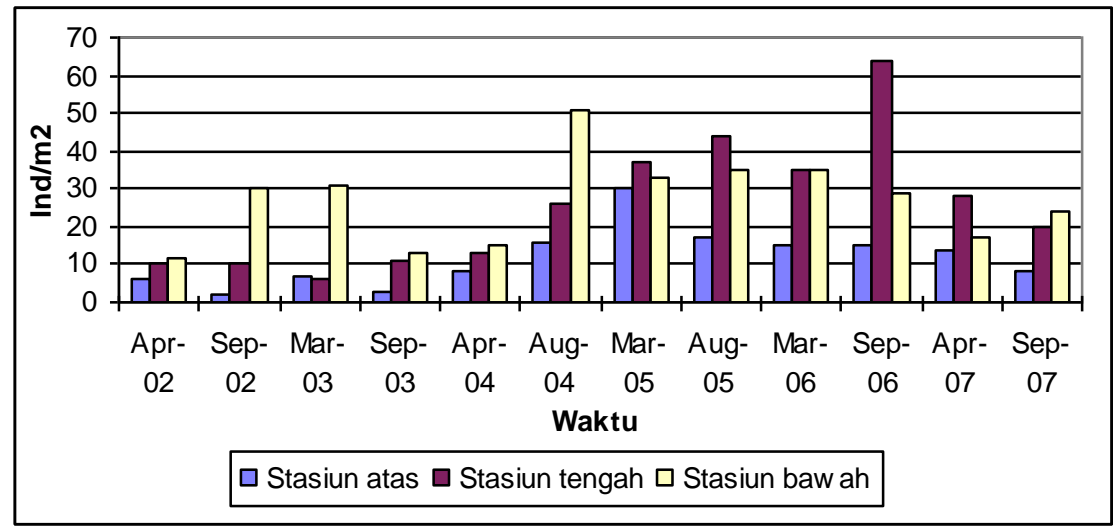

Gambar 5. Kepadatan fauna di Intertidal Madasamger selama tahun 2002 -2007.

Komunitas intertidal

Madasanger seperti daerah intertidal lainnya mempunyai daerah zonasi yang berbeda yang diperlihatkan kecenderungan keberadaannya. Populasi fauna cenderung lebih banyak di stasiun tengah dan bawah. Stasiun pasang tinggi (dekat pantai) Kepadatan fauna di daerah ini berkisar antara $3-30 \mathrm{ind} / \mathrm{m}^{2}$ dan mencapai puncak pada bulan Maret 2005. Stasiun Tengah mempunyai kedalaman yang agak dalam antara 0,5-1,2 meter karena topografi dasar agak cekung dengan tipe substrat pasir hingga pasir berkarang. Populasi fauna mencapai puncak pada bulan Agustus 2005 dan September 2006, serta menurun hingga September 2007. Kepadatan fauna di daerah ini berkisar 5-65 ind $/ \mathrm{m}^{2}$. Stasiun pasang rendah terletak dekat bibir tubir mempunyai substrat karang keras. Populasi fauna mencapai puncaknya pada bulan Agustus 2004, dan menurun terus hingga April 2007 serta meningkat lagi saat ini (September 2007). Kepadatan fauna berkisar antara $11-51 \mathrm{ind} / \mathrm{m} 2$.

Pantai intertidal Sejorong hampir mirip dengan Madasanger dan Mangkun, cukup lebar (300 meter) dengan substrat pasir padat dan pasir berkarang. Kondisi biota intertidal selama lima tahun tidak berubah secara signifikan meskipun terdapat perubahan sesaat pada beberapa komunitas lamun, komunitas karang, dan fauna. Populasi fauna mencapai bulanbulan puncak pada April 2004, Maret 2005, Maret 2006 dan September 2007. 


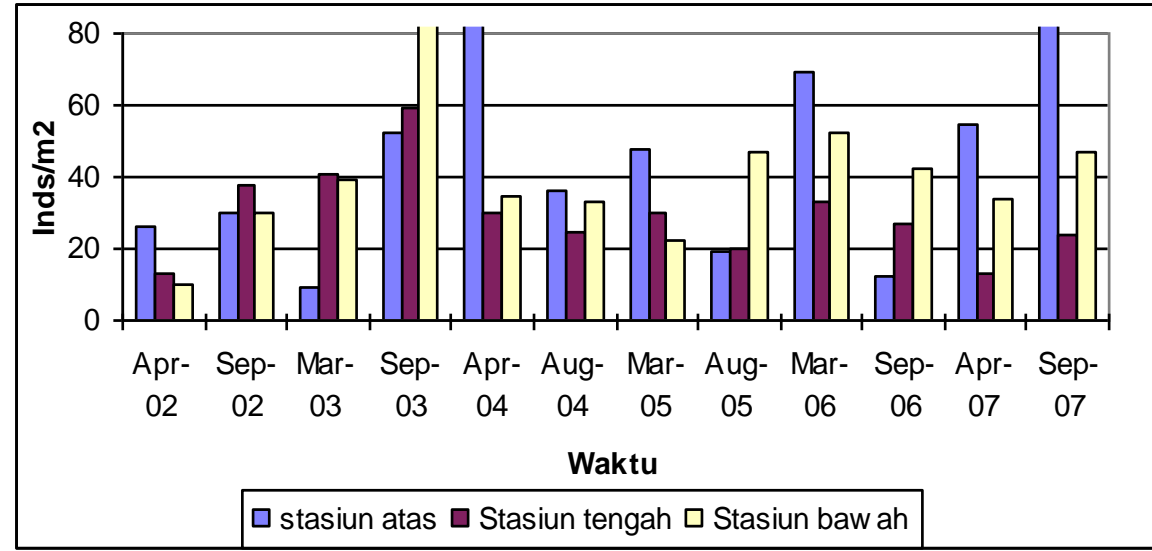

Gambar 6. Kepadatan fauna di Intertidal Sejorong selama tahun 2002 -2007.

Populasi fauna relatif berfluktuasi secara alami dengan puncak kepadatan terjadi pada bulan April 2004, Maret 2006 dan September 2007. Kepadatan fauna di daerah ini berkisar $10-82 \mathrm{ind} / \mathrm{m}^{2}$. Populasi fauna mencapai puncaknya pada bulan September 2003 dan setelah itu menurun hingga Agustus 2005. Setelah itu kepadatan fauna sempat naik sedikit dan hingga September $2007 \quad$ kepadatan berfluktuasi tidak terlalu signifikan. Kepadatan fauna bervariasi antara 12 hingga $60 \mathrm{ind} / \mathrm{m}^{2}$. Stasiun pasang rendah masih didominasi oleh rumput laut yang relatif konstan dengan tutupan berkisar 28-82 persen. Populasi fauna mencapai puncaknya pada bulan September 2003, setelah itu menurun dan mencapai puncaknya pada bulan
Maret 2006. Selanjutnya kepadatan fauna berfluktuasi tidak terlalu signifikan hingga September 2007. Kepadatan fauna di daerah ini berkisar $10-83 \mathrm{ind} / \mathrm{m}^{2}$.

Pantai Puna (Tongoloka) bersubstrat berbatu, lebar flat sempit, dan curam. Stasiun intertidal Puna mempunyai karakteristik yang berbeda dengan stasiun lainnya. Pantai yang berbatu umumnya didominasi alga yang tumbuh di atas batu atau di lakukan berbatuan, serta fauna yang memakan alga (grazer/herbivor). Kondisi biota intertidal umum tidak banyak mengalami perubahan secara signifikan meskipun terdapat fluktuasi secara alami (Gambar 7). Populasi fauna berfluktuasi dan tidak menunjukkan pola tertentu. 


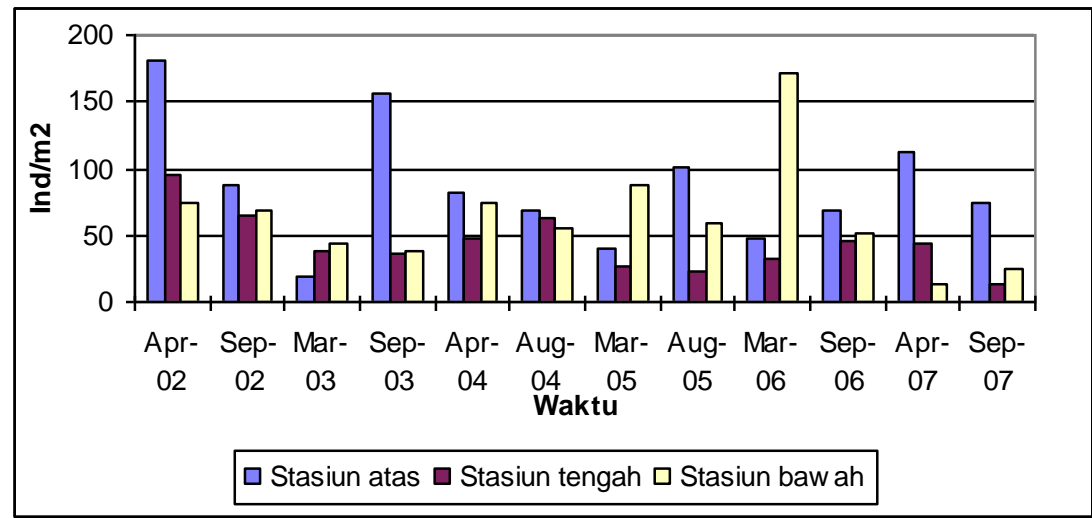

Gambar 7. Kepadatan fauna di Intertidal Puna selama tahun 2002 -2007.

Stasiun pasang tinggi (dekat pantai) umumnya kering pada saat surut, dan. Komunitas fauna memang cukup tinggi di daerah ini dan relatif stabil dengan kepadatan di atas rata-rata $50 \mathrm{ind} / \mathrm{m}^{2}$. Kepadatan moluska di daerah ini berkisar antara 20-180 ind $/ \mathrm{m}^{2}$. Jenis moluska yang dominan pada musim hujan (September) adalah Oyster/ Crassotrea sebanyak $26 \mathrm{ind} / \mathrm{m}^{2}$ dari kelas Pelecypoda. Sedangkan pada musim kemarau (April) adalah Littorrina sebanyak 94 ind $/ \mathrm{m}^{2}$ Stasiun tengah mulai banyak tergenang oleh air, dan beberapa cekungan yang tergenang air ditemukan lamun dengan tutupan berkisar 1-6 persen. Fauna tidak banyak mengalami perubahan secara signifikan kepadatannya sekitar 25$73 \mathrm{ind} / \mathrm{m}^{2}$. Stasiun pasang rendah didominasi oleh rumput laut dengan tutupan berkisar 38-73 persen. Komunitas karang makin baik di daerah ini dengan tutupan sebesar 10-34 persen. Kepadatan fauna mencapai puncak pada bulan Maret 2006 dan menurun secara alami hingga September 2007. Kepadatan fauna di daerah ini berkisar 20-170 ind $/ \mathrm{m}^{2}$.

\section{KESIMPULAN}

Kepadatan populasi moluska berfluktuasi pada setiap musim. Sebaran populasi meningkat pada musim hujan (September) dan menurun pada musim kemarau (April). Jumlah populasi moluska tertinggi terdapat di stasiun pasang tinggi pantai Puna (Tongoloka) yang bersubstrat berbatu, lebar flat sempit dan curam dengan kepadatan berkisar $20-180 \mathrm{ind} / \mathrm{m}^{2}$. Sedangkan jumlah populasi terendah terdapat di stasiun pasang rendah pantai Maluk yang bersubstrat berbatu, pasir hingga pasir berkarang dengan kepadatan berkisar 8 - $40 \mathrm{ind} / \mathrm{m}^{2}$. Jenis populasi yang dominan pada musim hujan adalah Oyster/Crassostrea dari kelas Pelecypoda Sedangkan pada musim kemarau jenis moluska yang dominan adalah Littorrina dari kelas Gastropoda.

Jenis molussca bervariasi tidak banyak perubahan yang ekstrim. Perubahan struktur komunitas dan kelimpahan masih dalam selang normal dan alami. Umumnya komunitas intertidal pada tahun 2007 tidak berada pada level minimal. Sebaran komunitas fauna 
tidak terlalu berbeda signifikan meskipun ada perubahan komposisi jenis tetapi biota penyusun utama masih ditemukan seperti bulu babi (sea urchin), brittle star dan polychaeta.

\section{DAFTAR PUSTAKA}

Nybakken, JW. 1993. Marine biology. An Ecological Approach 3 rd edition. HarperCollins College Publisher.

Sumich, JL. 1992. An introduction to the biology of marine life. WNC Brow Publisher. 